\title{
Tatbikat Planlaması ve Yönetimi
}

\author{
Muhittin DEMIRKASIMOĞLU ${ }^{1}$
}

\section{Öz}

Türkiye'de, kurumlar nasıl tatbikat yapacaklarını konusunda sorunlarla karşılaşmaktadır. Tatbikat planlama konusunda Türkçe kaynakların çok az olması, tatbikat planlamayla ilgili bilgiye ulaşmayı zorlaştırmaktadır. Tatbikat yapabilmek için iyi bir hazırık yapılmalıdır. Tatbikat hazırlanmasında planlama çok önemlidir. Tatbikat hazırlanmasında öncelikle tatbikat yapılma biçimine göre planlamanın nasıl yapılacağına karar verilmelidir. Amacına göre tatbikat senaryosu belirlenmeli, tatbikat zaman çizelgesi hazırlanmalı, görev dağılımı yapılmalıdır. Egzersiz sırasında gerçek olay veya kaza ile karşılaşıldığında ne yapıldığını bilmek gereklidir. Hazırıklar bölümünden sonra tatbikatın diğer aşamaları yer alır. Bunlar; tatbikatı yönetme biçimi, komutası, provaları, icra edilmesi, son değerlendirme ve raporlama şeklinde düzenlenmiştir. Bu yazı ile tatbikat planlama ve icra etme sürecinde olanlara kolaylık sağlanması amaçlanmıştır.

Anahtar Kelimeler: Tatbikat, planlama, yönetim, senaryo, zaman çizelgesi, emniyet pimi

\section{Drills Planning and Management}

\begin{abstract}
In Turkey, the institutions are facing problems in how to do the drills. The fact that there are very few Turkish sources about drill planning makes it difficult to reach information about the drill planning. A good preparation should be made to perform the drills. Planning is very important in preparing drills. While preparing the drills; first of all, it should be decided how to plan the drills according to the manner in which the drills are carried out. The scenario should be determined according to the purpose of the drills, drill timetables should be prepared, task distribution should be made. It is necessary to know what has been done when the actual incident or accident is encountered during the drill. After the preparations section, the other steps of the exercise take place. These steps are; the way to manage the exercise, to command it, the rehearsals, the execution of the exercise, final evaluation and reporting. With this article, it is aimed to provide convenience for those who are in the process of planning and executing the exercise.
\end{abstract}

Keywords: Drills, planning, management, scenario, timeline, safety pin

\section{GiRiş}

Tatbikat; Millî Eğitim Bakanlığının Örnekleriyle Türkçe Sözlüğü’ne (2000) göre uygulama, manevra, askeri birliklerin arazi üzerinde yaptıkları geniş ölçüdeki savaş denemesi olarak açıklanmaktadır. Bir acil durum veya afet hâlinde yapılması planlanmış olan müdahale sürecinde yer alacak eylemlerin uygunluğunu, yeterliğini ve güncelliğini mümkün olduğunca gerçeğe yakın koşullar altında ve bir senaryoya bağlı kalarak denemek amacıyla yapılan

\footnotetext{
${ }^{1}$ Türkiye Halk Sağıı̆ı Kurumu Erken Uyarı-Cevap ve Saha Epidemiyolojisi Dairesi İlgili yazar / Corresponding author: mdemirkasimoglu@yahoo.com Gönderim Tarihi: 30.11 .2018

Kabul Tarihi: 27.12.2018
}

Bu makaleye atıf yapmak için- To cite this article Demirkasımoğlu, M. (2018). Tatbikat Planlaması ve Yönetimi. Resilience, 145. 
uygulama. Masa başı tatbikatı, uygulama tatbikat (işlevsel tatbikat) ve genel tatbikat (tam ölçekli tatbikat) olarak farklı düzeylerde icra edilebilirler (Açıklamalı Afet Yönetimi Terimleri Sözlügü, 16.01.2017). Daha önceleri daha çok askeri terim olarak kullanılan terim, sivil terminolojide de kullanılmaktadır. Kurum, kuruluş ve işletmeler acil durum yaratacak olayların öncelik sırasına göre tespit edilmesi, bu acil durumlarda davranış yöntemlerinin belirlenerek işletme için Acil Durum Planı hazırlanması, bu planın çalışanlara ve Acil Durum Ekiplerine eğitiminin verilerek uygulamalı tatbikatlar yapmak tatbikat amaçlarındandır. Doğru uygulanması istenen konularda ekiplerin mevcut imkân ve kabiliyetleri ile yönetim usullerini denemek, birbiriyle iş birliği ve koordinasyonu geliştirmek, tespit edilen eksiklikleri gidermeye ve istenen konunun yönetimi imkân ve kabiliyetini artırmaya yönelik çalışmalara veri ve ivme kazandırmaktır.

Bu çalışma, her acil durum için risk değerlendirmelerini ve değerlendirme sonrası görev, yetki ve sorumlulukları tespit eden yöntemlerin oluşturulmasını içermektedir. Tatbikat planlamada ekip çalışması yapılmalıdır. Ekip çalışması sömürmek veya kendilerine dikte yapmak değil, saygı göstermek, teşvik etmek, coşku uyandırmak, insanları korumak, teşvik edilerek yapılmaktadır (Free Team Building Games, 2017). Çalışma kapsamında, acil durum yöntemlerinin kontrolü ve geliştirilmesi amacıyla eğitim ve tatbikat uygulamaları da yer almaktadır. Tatbikat öncesinde, kurumlara yönlendirme seminerleri ve alıştırma egzersizleri yaptırılarak, katılımcıların hazırlaması sağlanır, genel tatbikat türleri Masa Başı Tatbikatları, (Afete Hazırlık), Uygulamalı Tatbikatlar (Kurtarma ve Acil Yardım), Genel Tatbikatlar (Askeri, Ulusal-Uluslar Arası Kriz Yönetimi), Atölye çalışmaları, Oyunlar (Homeland Security, 2004), neden tatbikat bir acil durum veya afet öncesinde Acil Durum Eylem Planı içindeki afet müdahalesi eylemlerinin, uygunluğunu, yeterliliğini ve güncelliğini sınayarak değerlendirmek için yapılır sorusunu cevaplamalıdır (Özdemir, P. ve İlki, A., 2003). Afete müdahale mekanizmasının işleyişini deneme, Öngörülen politikalarla uyumluluğunu belirleme, insan gücü ve kaynakların yeterliliğini ve uygunluğunu belirleme, katılımcıların rollerini belirlemek ve imkânlarını geliştirme düşüncesiyle tatbikatlar yapılmaktadır.

\section{Yöntem}

Eğitim intiyaçları ve birim eğitim programları için öncelikleri belirlenmesi için analiz yapılmaktadır. Bu analiz, başlangıç veya sürdürme eğitimine intiyaç duyan bireysel ve toplu becerilere dayanan eğitim hedeflerini de belirlemektedir. Bunu yaparken, analiz, komuta ve kontrol eğitiminin üç kategorisi dikkate alınmaktadır: Eğitim alıştırmalarını etkin şekilde eğitilebilen bazı sistem ve hedefleri göstermektedir. "X", sistemin istihdamında veya belirtilen hedefe ulaşılmasında gerçekçi bir eğitim veren tatbikat programını belirtmektedir (Exercise planing, 2017). Tatbikatların amacına göre hedefleri olmalıdır. Tatbikat hedefleri planların doğru uygulanması ve hazırlanması açısından önemlidir.

- Planlanan hedeflere ulaşılıp ulaşılmadığını görmek ve ölçmek; bunun için objektif değerlendirme kriterleri belirlenmeli, ölçülmek istenenler ölçülerek istenen hedeflere ulaşılıp ulaşılmadığı değerlendirilmelidir.

- Ekiplerin birbiriyle, kurumlarla iş birliği ile koordinasyonu sağlamak ve geliştirmek; normal vakalarda, çoklu yaralanmalı kazalarda, Olağan Dışı Durumlarda (ODD) ve afetlerde ekiplerin aynı anda birçok vakaya müdahale etmesi gerekmektedir. Bu nedenle olay yerinde birçok vakaya aynı anda hizmet vermeye çalışırken kaos ve panik ortamının olmaması, birbirlerini tanıması, kimin ne zaman, nerede, neleri yapacağını bilinmesini sağlanmak.

- Bilgi destek faaliyetinin pratiğini yapmak ve geliştirmek; nadir yapılanların olay vuku bulduğunda şaşırmaması, müdahaleyi devamlı yapıyormuş gibi duraksamadan, hızlı ve sakin yapması, ekip çalışması yapmasını bilmeyenlerin pratiklerinin geliştirilmesi hedefine ulaşmak. 
- Raporlama usul ve esaslarını denemek; yapılan işlerin her an kayıtları tutulmak, kısa dönemde acil raporların hazırlanarak üst makamlara gönderilmesini sağlamak, görev bitiminde ise kati raporun oluşturulmasını sağlamak.

- Kurumun alarm sistemini çalıştırmak; kurum ODD'larda ne kadar hızlı tepki verdiğinin, doğru tepki verip vermediğini araştırmaktır.

- İlgili kurumun yönetiminin hazırlık pratiğini yapmak ve geliştirmek; ilgili kurumun sahada çalışan ekiplerinin verdiği tepkileri değerlendirmek, eksiklikleri tespit etmek, gerektiğinde anında müdahale edebilmek, yönetimin koordinasyonu sağlayıp sağlayamadığının da test edilmesi önemli olmaktadır.

- Eksiklerin görülmesi ve yeni önlemlerin alınmasını sağlamak; tatbikatın en önemli hedeflerinden birisi kurumun tatbikatla eksikliklerinin görülerek gerçek olaylarda aynı sorunlarla karşılaşılmasının önüne geçilmesine yönelik önlemlerin alınması, kurumun kendi eksikliklerini görebilmesini sağlamaktır.

- Yeni Eğitim Planlaması; tatbikat sonu değerlendirme sonucu kurumun eksikliklerini görmek, bu eksiklikleri gidermek, geliştirmesi gereken konularda kendisini geliştirmesi vb diğer konularda eğitimlerin planlanmasını sağlamak.

- Geleceğe Yönelik Hedeflerin Planlaması; tatbikatta görülen eksiklikler, tatbikat sonucu değerlendirmeler sonucu verilen yeni eğitimlerle kuruma yeni vizyon ve misyonları yüklemektir.

\section{Yapılış Şekline Göre Tatbikat Türleri}

3.1.Seminerler, Seminerler genellikle katılımcıları, otoritelere, stratejilere, planlara, politikalara, prosedürlere, protokollere, kaynaklara, kavramlara ve fikirlere yönlendirmektedir. Ayrıca, mevcut plan veya prosedürlerde önemli değişiklikler yapan veya yargılayan bölgeler için iyi bir başlangıç noktası sağlamaktadır.

3.2. Atölye Çalışmaları (Çalıştaylar), Tatbikatların yapı taşı yaklaşımında ikinci etaptaki çalışmaları ortaya koymaktadır. Seminerlere benzese de çalıştaylar iki önemli açıdan farklıdır: katılımcı etkileşimi artar, odaklanma bir ürün elde etmeye veya inşa etmeye (ör. Planlar ve politikalar) yöneliktir. Bilgi toplamak veya paylaşmak, yeni veya farklı perspektifler edinmek, yeni fikirleri, süreçleri veya prosedürleri test etme, koordineli faaliyetleri yerine getirmek için eğitim grupları, karmaşık sorunları çözme, fikir birliğinin sağlanması, yeni Standart Operasyon Prosedürleri (SOP) veya Operasyon Çalışma Prosedürleri (OÇP) ortaya konabilmektedir.

3.3. Masabaşı Tatbikatlar, genel farkındalığı artırmak, planları doğrulamak ve süreyi test etmek ve / veya tanımlanmış bir olaydan korunma, yanıt verme ve iyileşmeyi yönlendirmek için gerekli sistem türlerini değerlendirmek, kavramların anlaşılmasını kolaylaştırmak, güç ve eksiklikleri belirlemek ve / veya tutum değişikliğinin sağlanmasını amaçlamak için kullanılmaktadır.

3.4. Oyunlar, oyuncu eylemleri tarafından yönlendirilen varsayımsal durumlardır. Üzerinde yürürlükte bir oyun (bundan sonra bir oyun olarak anılacaktır) belirli kurallara sahiptir ve parametrelerini uygulamak için denetleyicileri kullanmaktadır. Oyunlara katılanlar, tatbikat amaçlarına bağlı olarak aynı disiplinden veya farklı disiplinlerden ve / veya aynı yargı kararından veya birden fazla yargı alanından gelebilmektedir. Bu tür tatbikat, oyuncunun yanıtlarının sonuçlarını araştıı ve katılımcıların eylemlerinin olası sonuçlarını anlamalarına yardımcı olmak için kullanılabilmektedir.

3.5. Modeller ve Simülasyonlar, ulusal güvenlik tehditlerini kavramak ve tepki kavramlarıyla çalışmak için değerli araçlardır. Modeller ve simülasyonlar, belirli bir senaryo bağlamında oyunculara anında geri bildirim sağlayabilmektedir. Canlı tatbikatlar herhangi bir hazırlık 
programının vazgeçilmez bir bileşeni olmasına rağmen, simülasyonlar, yurttaş güvenliği topluluğunda bulunan kaynakları ve bunların kullanımını önceden önermek için olan zorlukları, uygun maliyetle gösterebilmektedir. Canlı tatbikatları tamamlamak için kullanıldığında, modeller ve simülasyonlar tatbikat denetleyicileri ve değerlendiricilerin simüle edilmiş bir kimyasal veya biyolojik maddenin etkilerini tahmin etmek için kişisel uzmanlığa güvenmeleri yerine, sistematik veri toplama ve analiz yapabilmektedir.

3.6. Foksiyonel Tatbikatlar, bir fonksiyonda bireysel yetenekleri, çoklu fonksiyonları veya faaliyetleri test etmek ve değerlendirmek üzere tasarlanmıştır. Fonksiyonlar tatbikatlar genelde, kilit personelin Acil Durum Komuta Sistemi'nde görevlendirdikleri fonksiyonu yerine getirme fırsatı sağlayarak planları, politikaları ve prosedürleri uygulamaya odaklanmaktadır. Genellikle olaylar, faaliyet seviyesini yönetim düzeyinde yönlendiren olay güncellemeleri içeren bir tatbikat senaryosu yoluyla tahmin edilir. Personelin ve ekipmanın hareketi simüle edilir. Fonksiyonlar tatbikatların amacı belirli fonksiyonel ekipler içerisinde, kriz koşulları altında belirli planları, politikaları ve prosedürleri uygulamaktır. Bir Fonksiyonlar tatbikatlar, yüksek stresli bir çevrede eğitimli personel tarafından hızlı ve etkili yanıtlar gerektiren karmaşık ve gerçekçi problemleri sunarak işlevsel bir alanda operasyonların gerçekliğini simüle etmektedir.

3.7. Operasyon Temelli Tatbikatlar (bir operasyonun tatbikatı): Operasyon tabanlı tatbikatlar, tatbikat döngüsünün bir sonraki seviyesini temsil eder; tartışmalara dayalı tatbikatlarda katılaşan planları, politikaları, anlaşmaları ve prosedürleri doğrulamak için kullanılmaktadır. Operasyon tabanlı tatbikatlar arasında matkaplar, fonksiyonel tatbikatlar ve tam ölçekli tatbikatlar bulunur. Rolleri ve sorumlulukları açıklığa kavuşturabilir, plan ve prosedürleri uygulamak için gerekli olan boşlukları belirleyebilir ve bireysel ve takım performansını geliştirebilirler. İşlemlere dayalı tatbikatlar, gerçek yanıt, cihazların ve kaynakların harekete geçirilmesi ve personel taahhüdü ile karakterizedir; genellikle uzun bir süredir.

3.8. Tam Zamanlı Tatbikatlar (TZT), tatbikat döngüsündeki en karmaşık adımdır. Tam ölçekli tatbikatlar, hastanelerin acil müdahale ve kurtarma planları ve prosedürlerinin birçok yönünü sınar. Bunlar, bir olayın etkin ve etkili bir şekilde yanıtlanması ve bu olaydan kurtarıması için örneğin, Hastane Afet Planı (HAP) gerçek tam zaman kullanımını içerir. Benzer şekilde 112 acil sağlık, ulusal ölçekteki AFAD tatbikatları ile askeri tatbikatlar da tam zamanlı tatbikatlardır (TZT). Bir TZT, tartışma tabanlı tatbikatlarda geliştirilen planları, politikaları ve prosedürleri uygulamak ve analiz etmek ve önceki, daha küçük, operasyon tabanlı alıştırmalar üzerine odaklanmaktadır. Olaylar, güncellemelerin etkinliği sürmesine izin vermek için yerleşik esnekliğe sahip komut dosyası kullanılmış bir alıştırma senaryosu yoluyla tahmin edilir. Gerçek bir olayı yakından izleyen gerçek zamanlı, stresli bir ortamda yürütülür. Hastane kaynakları, gerçek bir olay meydana gelmiş gibi eylemler (dekontaminasyon, triaj, Emergency Operation Center, vb.) Yaptıkları yere seferber edilir ve konuşlandırılır. Tam zamanlı tatbikat, oldukça stresli bir ortamda, eğitimli personelin eleştirel düşünme, hızlı problem çözme ve etkili tepkiler gerektiren karmaşık ve gerçekçi sorunları sunarak operasyonların gerçekliğini taklit eder. Alıştırmada yer almayan, ancak gerçek bir olaya karışacak olan diğer kuruluşlar, tatbikatta "simüle edilmiş" bir kaynak olarak "oynayabilir". Bir tam ölçekli tatbikatlar, oldukça stresli bir ortamda taklit edilen bir canlı etkinlik karşısında HAP'ları, prosedürlerini ve karşılıklı yardım anlaşmalarını yürütmek için bir fırsat sağlar. Çalışma Usulleri (SOP), planlar, politikalar ve prosedürler. Askeri tatbikatlar, ulusal ölçekteki afet tatbikatları ve kurumsal tatbikatlar, HAP tatbikatlarındaki gibi, bilinen senaryo üzerinden var olan süreçleri, standart operasyon usullerini tekrarlayarak, tatbikatın plana göre yürüyüp yürümediğini kontrol etmektir. Herhangi bir tam ölçekli tatbikatlar yürütmek için gereken destek seviyesi diğer tatbikat türleri sırasında gerekenden daha yüksektir (Homeland Security, 2004; Exercise planing, 2017, FEMA, 2017). 


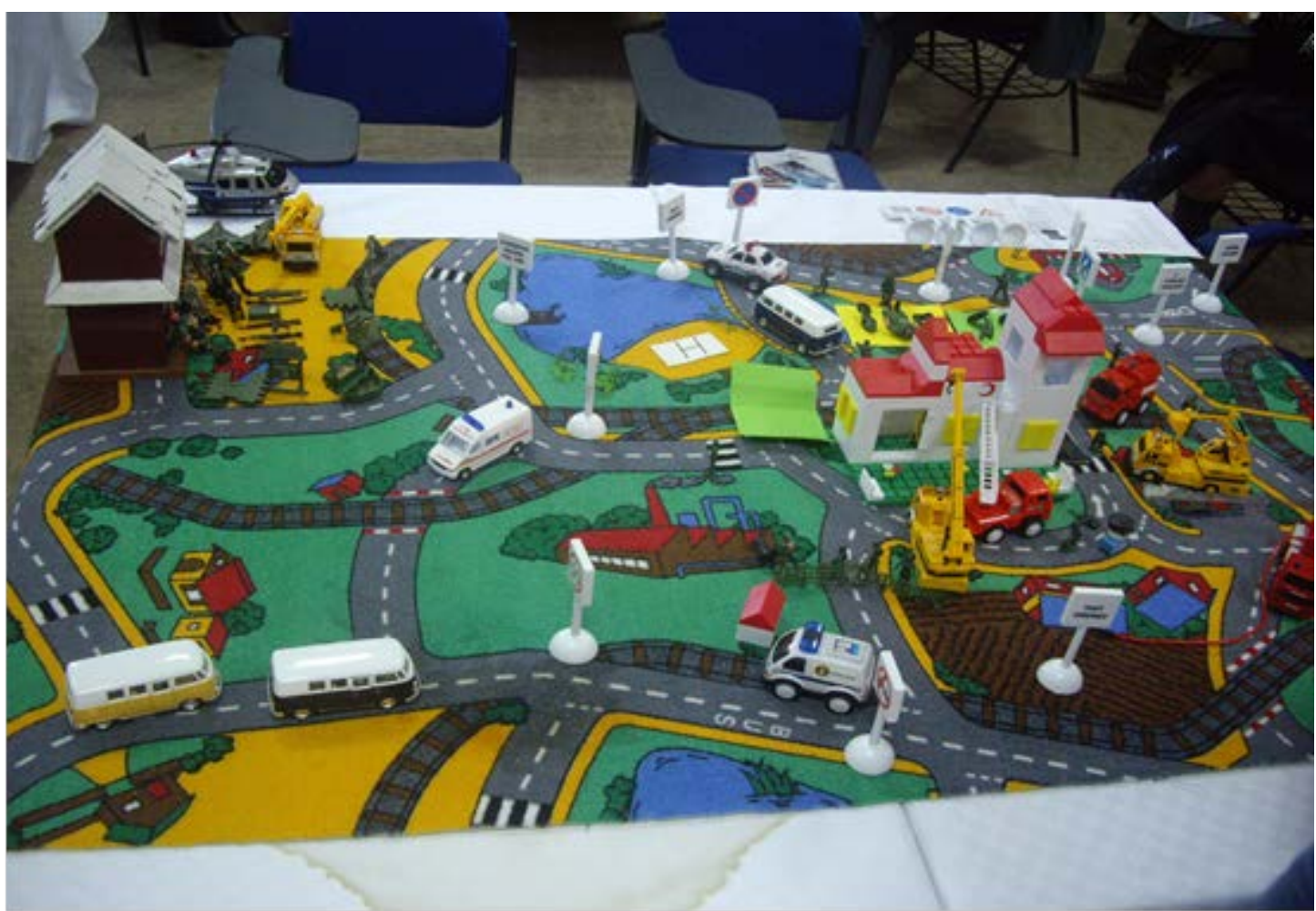

Şekil 1: Masabaşı Tatbikat Örneği (Hastane Afet Planı Eğitimlerinden)

Planlama aşaması, esnekliğin değerini ve kapsamlı olmanın gerekliliğini tanımlamaktadır. Planlamacılar, hava koşullarının veya diğer kısıtlamaların başlangıçta planlanan tatbikatın yapılamaması durumunda, alternatif tatbikat türleri için plan yapmaktadır. Mevcut doktrin, taktik, teknikler ve çalışma usulleri çerçevesinde yenilik yapma özgürlüğüne izin vermektedir. Eğitim ve öğrenmeyi engelleyen katı zaman çizelgeleri takip edilmemektedir. Bunun yerine, hataları düzeltmek ve her düzeyde öğrenme sağlamak için yeterli zaman sağlayan programlar oluşturulmaktadır. Tatbikatın gerçekleştirileceği eğitim hedefleri ve öneriler, ölçek ile zamanlama, adımları ne kadar karmaşık hale geleceğini düşünerek tatbikat yapmaktan vazgeçilmemelidir. Planlamanın çoğu eğitim toplantıları sırasında gerçekleşip şekillenecektir. Bununla birlikte, bölüm seviyesinde, araştırma ve yazılı planlama çizelgeleri gereklidir. Başarılı bir tatbikatın anahtarı bu çizelgeler olabilecektir (Exercise planing, 2017). Planlama ekibi yeterli sayıda kişiden oluşmalıdır. Daha fazlası kaosa yol açacaktır. Dışarıdan dış kurumlar için destek alınabilir, ancak asıl planlama ekibi için beş kişilik sayı idealdir. Planlamacılar, egzersiz ve hava etkileri için ortamı düşünmektedirler. Eğer yetersiz arazi veya tesisler eğitim kalitesinde ciddi bir düşüşe neden olacaksa, planlamacılar egzersizleri değiştirebilmektedirler. Planlar ile emirlerin hazırlanması ve verilmesi. Tatbikatlar özel araziyi kullanırken, planlamacılar da manevra hasar kontrolünü düşünmektedir. Eğitim tatbikatları destek gerektirmektedir (Exercise planing, 2017). Olay Niteliğinin tespiti, kurumun eksikliğinin neler olduğunu tespit etmek için tatbikat yapılmaktadır. Eksikliklere göre olayın niteliğine göre olay düşünülmektedir. Düşünülen olaya göre ekipler, yer, zaman vb konular planlama içinde yer almaktadır. Yapılması istenenlerin tespiti, tatbikatın amacı ve hedefine göre belirlenmektedir. Ekiplerin ne yapması istendiği kurumsal vizyon ve misyona göre veya yönetimin isteğine göre planın içine konulmaktadır.

Tatbikat hedeflerinin tespiti, yönetim ve tatbikatı yürütecek ekip tarafından planlama aşamasında hedefler (ölçülebilir) konulmaktadır. Hangi tür tatbikat yapacağını ve belirli eğitim hedefleri belirtilmektedir. Tatbikatın zaman çizelgesi, fiziksel konumu ve uygulama evresinin 
süresi gösterilmektedir. Konumu, zamanı ve süresi, seçilen tatbikatın türüne, katılımcı ünitelere ve eğitim hedeflerine uygun olmaktadır. Katılımcı birimlerin türü ve sayısı belirtilmektedir. Gerekli özel ekipmanın tipi ve miktarı belirlenmektedir. Finansman, çevre ve ilgili varsayımlar gibi ek bilgiler sağlanmaktadır. Diğer bütün işlemler tatbikat süresi ile yakından ilişki içindedir. İhtiyacı duyulan personel sayısının tespiti; planlama ekibi tatbikat büyüklüğüne göre personel planlaması yapılmaktadır. Planlama esnasında tatbikatın izindeki veya yedek personelle mi yoksa bizzat görevi başındaki ekip tarafından mı yapılacağına karar verilmektedir. İhtiyaç duyulan malzemenin çeşidi ve miktarları önceden tespit edilmektedir. Tatbikatın amacı ve senaryosuna göre malzemelerin çeşitleri ve miktarları belirlenmektedir. Güvenlik bantlarından ışıklı levhalara kadar kullanılabilecek her bir malzeme düşünülmelidir. Planlamacılar, tatbikat için ayrılan araziyi en verimli şekilde kullanmalıdır. Mümkünse, güncellenmiş hava fotoğrafları bulunan alanların güncel haritalarını incelemelidirler. Gözlem ve yangın alanları, örtme ve gizleme, engeller, önemli arazi ve ulaşım yolları gibi afet/Olağan Dışı Durum (ODD) özelliklerini belirlemek için araziyi analiz etmelidirler. Tatbikatın yapılacağı yer, tatbikatı yapan yerin ise önceden diğer birimlere haber verilmektedir. Eğer başka kurumun ise önceden resmi izinlerinin alınması için gerekli yazışmaların yapılması için planlama yapılmaktadır.

Tatbikat iletişiminin planlaması, ne tür iletişim araçları kullanılacağı, tatbikat alanı ile merkez arasındaki haberleşmenin sağlanması, tatbikat içi haberleşmenin sağlanması planlanmaktadır. Tatbikat disiplin kurallarının konulması planlama açısından ve tatbikatın başarısı yönünden değerlendirilmesinde şarttır. Ekibin ciddiyeti tatbikattaki amaç ve hedefler için elzem olan bir konudur. Tatbikat güvenliğinin planlaması iki açıdan ele alınmaktadır. Tatbikat ekiplerinin güvenliği ile tatbikattaki canlı manken kullanılıyorsa bu kişilerin güvenliği ile tatbikatta çalışanların dışında seyreden veya oradan geçenlerin güvenliği mutlaka sağlanmaktadır. İzleyiciler için şeritlerle alanlar belirlenmekte, bu kişiler güvenli alanlarda tutulmasına yönelik planlama yapılmaktadır. Gerekli ise güvenlik kuvvetlerinden destek talep edilmektedir. Diğer kurum ve kuruluşlarla iş birliği ve koordinasyonun planlanması gerekir. İş birliği gereken kurum ve kuruluşlarla yakın çalışılmalıdır. Tatbikat yapılacak alandan (yer/yol vb.) ortak kullanılacak komuta, çadır, araç gibi iş birliği ile koordinasyonun nerede ve nasıl kullanılacağı ayrıntısı ile planlanmalıdır. Tatbikatın kendisi yapılmadan önce provaların da kaç kez yapılacağının karar verilmesine kadar planlanmaktadır. Lojistik ve ikmalin planlanması yapılmakta, tatbikatın süresine göre tatbikat ekiplerinin yemesi içmesi, lojistik malzemelerinin temininin planlanması açısından büyük öneme sahip olmaktadır. Tatbikatta kullanılacak malzeme teknik destek ekibi olan lojistik ekibi tarafından sağlanmaktadır (Exercise planing, 2017).

\section{Hazırlık}

Planlama yapılması, yapılacak tatbikatın her aşamasının planlanması düşünülmektedir. Planlama grubu senaryoyu yönetimin isteğine göre oluşturmaktadır. Bazı senaryolar yönetimin bilgisi dışında (içeriği ve tarihi dahil) planlama ekibi tarafından hazırlanmaktadır. Yönetim ile kurumun tepkisini ölçmek için yönetim, tatbikatın varlığından ve yapılacağı zamandan haberdar edilmeyebilir. Planlama ekibi aynı zamanda tatbikat zaman çizelgesini yapmaktadır. Planlamacılar, tatbikat ile gerçek güvenlik ve istihbarat önlemlerini her zaman ayırt eder. Güvenlik talimatları; maksimum gerçekçilik elde etme çabası, tehlikeli koşulların ortaya çıkmasına ve durumların ortaya çıkmasına neden olabilmektedir. Bu tehlikeler, tatbikatın yanı sıra bireysel katılımcılar ve yerel sivil topluluklar üzerinde olumsuz etkilere neden olabilecektir. Kazaları ve yaralanmaları en aza indirgemek için planlayıcılar, tatbikata başlamadan önce tüm birimler için özel emniyet talimatları hazırlamalı ve yayınlamaktadır. Bu talimatların uygulanmasından egzersiz alanındaki kontrol personeli sorumludur. Bununla birlikte, güvenlik kurallarını yayınlama, netleştirme ve uygulama için oyuncu birimleri içindeki komuta sorumluluğu azalmaktadır. Planlama amacı; kurumun eksiklikleri, vizyonu ve 
misyonu içindekileri test etmek olabileceği gibi kurumsal olarak yeni bir iş (mal veya hizmet üretimi) yapılmasının öğretilmesi de olabilmektedir. Planlama grubu verilen eğitimi ve eğitimcileri ölçmek amacıyla da senaryo ve tatbikatı çok boyutlu oluşturmaktadır. Tatbikatın süresine uyup uymadığı provalarda kontrol edilmektedir.

Tatbikat Türü, düşünülen amaca göre tatbikatın türüne karar verilmelidir. Amaç öğretmek ise haberli tatbikat, amaç verilen tepkinin ölçülmesi ise habersiz tatbikat yapılmalıdır. Haberli tatbikat, yarı haberli tatbikat, habersiz tatbikat, "x gün" tatbikatlarından birisi olmalıdır. Senaryo hazırlanması, kurumun gördüğü eksikliğe yönelik olarak planlanmalı ve türüne göre zaman çizelgesi ilgili kişiler tarafından hazırlanmalıdır. Tatbikata göre senaryo belirlenmelidir (Esin vd., 2001).

Malzeme Planlaması, lojistik birimi ile birlikte tatbikatın türü ve senaryosuna göre kullanılması muhtemel olan bütün malzemeler önceden hazırlanmalıdır. Personel Planlaması, tatbikatın türüne, senaryoya ve büyüklüğüne göre personel görevlendirilmesi yapılmalıdır. Personel planlamasında görevdeki personel mi yoksa görev harici personel tarafından mı tatbikat yürütüleceği tatbikatın türü ile yönetimin tercihine bağlı olmalıdır. Toplantılar, tatbikatın türüne göre toplantıların büyüklüğü, sayısı ve niteliğine göre hazırlık yapılarak düzenlenmelidir. Görev Dağılımı; tatbikatın amacı, hedefleri, senaryo ve türüne göre görevlendirilecek personele görev dağılımı yapılarak bu kişilere görevleri tebliğ edilmelidir. Bu tatbikatta herkesin görevleri görev tanımları bildirilmeli, kimlerden emir alacaklar, kimlere emir verecekler, hiyerarşini nasıl olduğu ayrıntılı biçimde bildirilmelidir. Denetleyiciler, hakemler ve değerlendiriciler tatbikat alıştırmalarının etkin ve verimli çalışması için şartır. Denetleyiciler olayların olay senaryosuna ve olay takvimine uygun zamana ve yerde gerçekleşmesini sağlar. Kontrolörler, fiziki olarak oyuncu olarak bulunmayan tüm karargahları ve birimleri temsil eder. Değerlendiriciler, önceden belirlenmiş standartlara göre görev yapıp çalışmadıklarını belirlemek için oyuncuların ve oyuncu ünitelerinin faaliyetlerini gözlemlemektedir. Her denetleyici, değerlendirici ve hakem, egzersiz süresince belirli bir bölüme atanır.

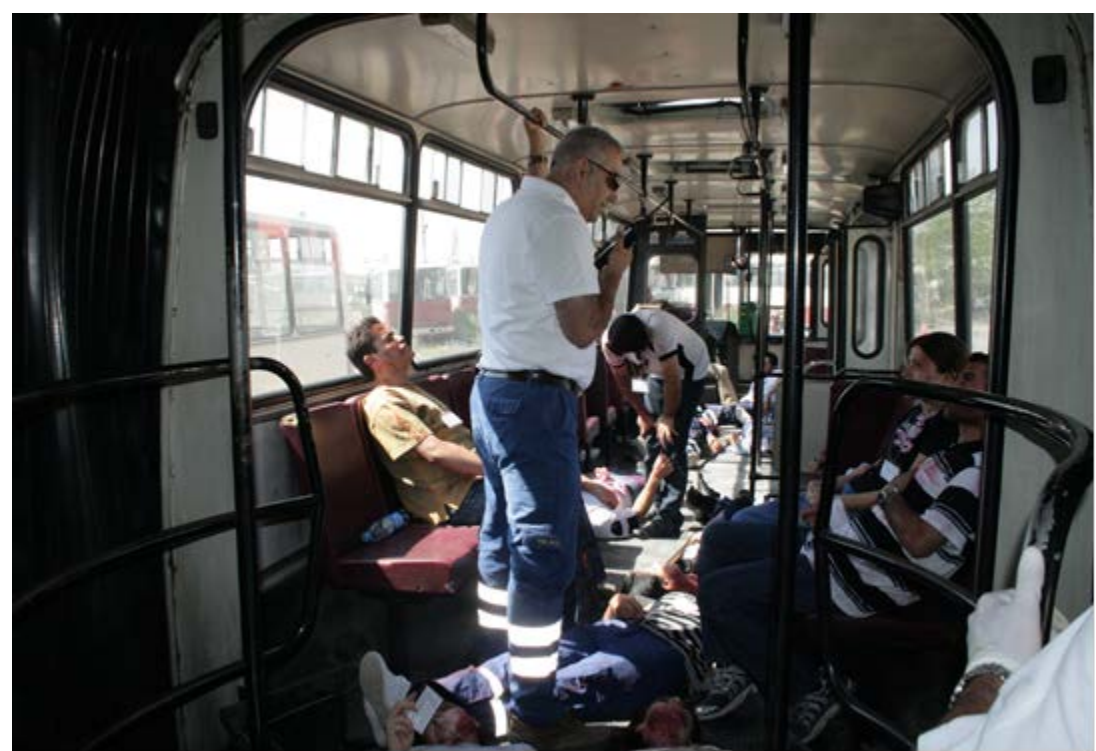

Şekil 2: Haberli Tatbikata Örnek

Baş kontrolör, bu spesifik görevleri tatbikatın kapsamına, mevcut personel ve gerekli ekipmana dayalı olarak kontrol eder. Mümkünse, değerlendirici olarak görevlendirilen personel, değerlendirilmekte olan konum konusunda deneyime sahip olmalıdır. Mümkün olduğunda, komutanlar komutanları değerlendirmelidirler. Görevlerini yerine getirmek için kontrolörler, hakemler ve değerlendiriciler eğitilmelidir. Eğitim miktarı, bu kişilerin geçmişleri 
ve deneyimleri ile egzersizin ölçeğine bağlıdır. Tatbikatlarda hemen herkes eğitime alınmalıdır. Rol dağıtımında geçmiş tecrübeler göz önüne alınmalıdır (Exercise planing, 2017).

Zaman Çizelgesi Oluşturulması, tatbikatın türüne göre zaman çizelgesini hazırlayacak kişi/kişiler değişir. Haberli tatbikatta tatbikat planlama ekibi senaryoya göre zaman çizelgesini oluşturur. Katılımcılar, denetimciler ve yöneticiler zaman çizelgesini bilir. Zaman çizelgesine göre süre oynanır. Sapmalar not edilir. Nedenleri araştırılır.

Diğer Kurum ve Kuruluşlarla yapılan iş birliği ve koordinasyonun planlanması için bağlantıya geçilmesi, provaların yapılması, tatbikat yapılacak alanda (yer/yol vb.) ortak kullanılacak komuta, çadır, araç gibi iş birliği ile koordinasyonun nerede ve nasıl kullanılacağı ayrıntısı ile belirlenmelidir. Gerekli izinlerin alınması için önceden resmi yazışmaların yapılması gerekmektedir. Tatbikat yapmak için arazisi kullanılacak kurumdan kullanılacak alan dışında malzeme ve ekip de isteniyorsa resmi talep yazısında bunlar da belirtilmelidir. Tatbikat yapılacak alan kamusal alan ise valilikten resmi izinler talep edilmeli, güvenlik birimleri dahil olaydan haberdar edilmek üzere resmi yazıları yazılmalıdır.

İletişim, olayları yönetmenin veya işi doğru yapmanın daha doğrusu başarının anahtarı olan bir ifadedir. Illetişim olmazsa başarı şansı çok düşüktür. Olay yeri ile komuta merkezi, komuta merkezi ile yönetim merkezi, yönetim merkezi ile katılımcılar, katılımcıların birbirleri arasındaki iletişimin sağlanması şarttır. Yönetim çok başı olacağı gibi koordinasyon ve işbirliği sağlanması mümkün olmaz. İletişimin nasıl sağlanacağı belirlenmeli, alternatifleri düşünülmeli ve hazır tutulmalıdır. İletişim için VHF-UHF, VHF ve HF telsizlerin kullanılması, dijital veya analog telsiz sistemlerinin kullanılması, simpleks görüşmelerin düşünülmesi, telli, telsiz telefonların planlanması yapılmalıdır. Bas konuş sistemleri, uydu telefon sistemleri alternatifler içinde düşünülmelidir. Her türlü iletişimin durması halinde ulak sisteminin de aklın bir köşesinde tutulması yararlı olacaktır. Her bir ekip için iletişim şekillerinin belirlenmesi, bu ekipler için kodların ve isimlerin verilmesi şarttır.

Tatbikat Komutası, senaryoda en etkin biçimde tanımlanmalı görevleri açıkça belirtilmelidir. Komuta, olay yeri yönetimi, komuta merkezi yönetimi ve olay komuta yönetimi şeklinde kendini gösterir. Tatbikat güvenliği sağlanmalı, izleyicilerin bulunacakları alanlar güvenli alanlar olarak tespit edilmeli, bu yerlere güvenlik bariyerleri/şeritleri konulmalıdır. Tatbikat uygulayıcı ekipleri bu konuda uyarılmalıdır. Tatbikatta canlı mankenler kullanılacak ise bu kişiler için güvenlik pimi denilen parola belirlenerek herkesin bunu bilmesi sağlanmalı, sık sık kontrol edilmelidir. Tatbikat alanına görevliler dışında hiç kimsenin girmemesi sağlanmalıdır. Tatbikatta ve öncesinde provalarda ekiplere yiyecek içecek temini sağlanmalıdır. Ekip her açıdan eksiksiz alanda prova ve tatbikatlarını icra etmelidir. Raporlama ve değerlendirme yapılması, tatbikat sırasında, sonrasında senaryoya göre raporların verilmesi planlanmalıdır. Tatbikat sonunda ise tatbikatın kendisi değerlendirilerek, olumlu yönler, geliştirilmesi gerekenler ve öneriler başlıkları altında rapor hazırlanmalıdır.

\section{Tatbikat Belgeleri}

Tatbikat belgelerinin amacı, kılavuzluk etmek ve yönetmektir. Tatbikat belgesinin açık kısmında; tatbikatın spesifik hedefleri belirtilir ve tatbikatın nasıl değerlendirileceği belirtilir. Tüm pratik konular ve talimatlar katılımcıların tatbikata açık bir bakış açısı getirmesi için ayrıntılı olarak tanımlanmalıdır. Gizli doğanın hiçbir şeyine burada yer verilmemelidir, sadece katılımcıların tatbikattan en iyi şekilde yararlanmak için bilmeleri gereken yönler. Tatbikat şartları, katılımcılardan çeşitli çalışma gruplarına önceden tatbikatta bulunan herkese gönderilmelidir. Alıştırmanın taahhüdü, değerlendirme ve işleme için bir temel oluşturur. Geribildirim yanı sıra bir sonraki alıştırmayı planlamak için bir temel sağlar. Aşağıda, genel 
olarak alıştırmalar için temel belgeler bulunmaktadır: Görev beyanı, danışmanlık sözleşmesi, taraflar arasındaki anlaşmalar ve resmi yazışmalar, tatbikat planı, faaliyetlerin tanımı ve faaliyet planı, proje bütçesi, masa saati, proje sapmaları, tatbikat için şartlar (alan, haritalar, resimler, tuvaletler, yemek alanları, vb.), tatbikat yönetimi için referans şartları, güvenlik önlemleri ve güvenlik yönetmelikleri, gizlilik politikası - gizlilik için referans terimleri, iletişim için referans şartları, katılımcı organizasyonun iletişim listesi, değerlendirme dokümantasyonları, tatbikat proje raporu, katılımcıların değerlendirme raporu, tatbikat projesinin değerlendirme raporu, tatbikat için zaman çizelgesi (tatbikatın gerçekleştirilmesi için zamanlamalar), tatbikat şekli ve yöntemi, işbölümü ve sorumluluklar, hedefler - ana hedefler ve kilometre taşları, organizasyon, katılımcılar, tatbikat yönetimi, senaryo, geçmiş deneyimler ve olaylar ve başlangıç konumu, zaman tablosu - başlat, geçişler ve benzeri, teknik ve iletişim konularını içermelidir (Wilhelmson ve Svensson, 2014).

\section{BILINIRIRLIĞE GÖRE TATBIKAT TÜRLERI:}

\subsection{Haberli Tatbikat}

- Bu tatbikat türünde Senaryo ve nerede yapılacağı bellidir. Önceden ilgili yerlerden resmî izinler alınmıştır. Bu yönde yazışmalar tamamlanmıştır. Tatbikat ekibi tatbikat alanını, bilmekte, senaryoda kimlerin görevleri var kimlerin yok, kimler hangi görevleri ve nasıl yapacak bilinmektedir. Senaryo zaman çizelgesi içinde yapılacak neredeyse dakika planlanmış ve tatbikatı icra edecek ekibe anlatılmalıdır. Haberli tatbikatın amacı ekibin bildiği veya öğrenmesi istenen yapıyı ayrıntısına kadar eksiksiz yapmasını sağlamak ve alışkanlık ile serilik ağlamaktır.

- Ne zaman olacağı ve Kimlerin katılacağı herkesçe bilinir. Haberli tatbikatta zaman çizelgesi bilineceğinden kimin ne kadar süre sonra ne yapacağı, gerçek olayda ise karşılaşılan olayda bir sonraki adımın ne olacağını önceden bilmesi adımları ile tutum ve davranışlarını buna göre belirlemesi istenmektedir. Ekipleri bileceği için bu ekiplerle gerçek olaylarda teklemeden kimin ne yapacağı önceden bilinerek hata riski azaltılması amaçlanmıştır.

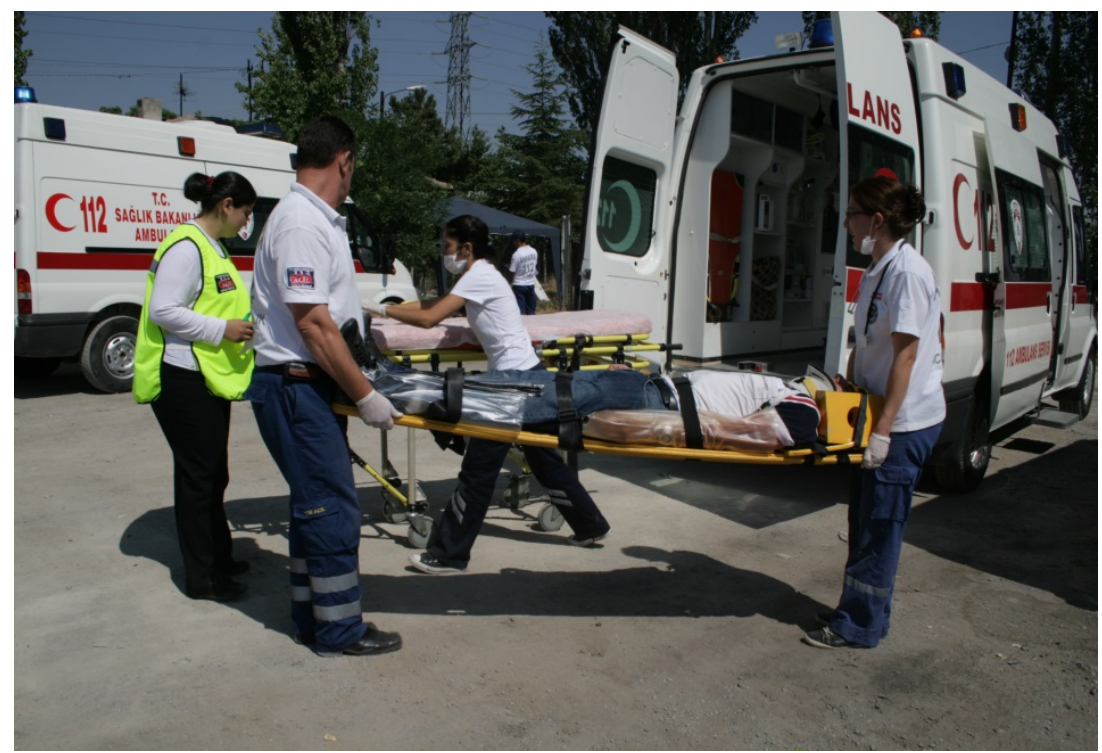

Şekil 3: Ankara UMKE- Ankara 112 Ortak Çoklu Yaralanma Tatbikatı

- Katılımcılara senaryoya göre ne yapmaları istendiği anlatılır. Senaryo içeriği ve süresi bilineceğinden katılımcıların aklında soru işaretleri bulunmayacaktır. Tatbikat provalarında katılımcıların yapacağı hatalar prova kesilerek gösterilebilir. Provalarda ekiplere yapılacaklar adım adım gösterilir. 


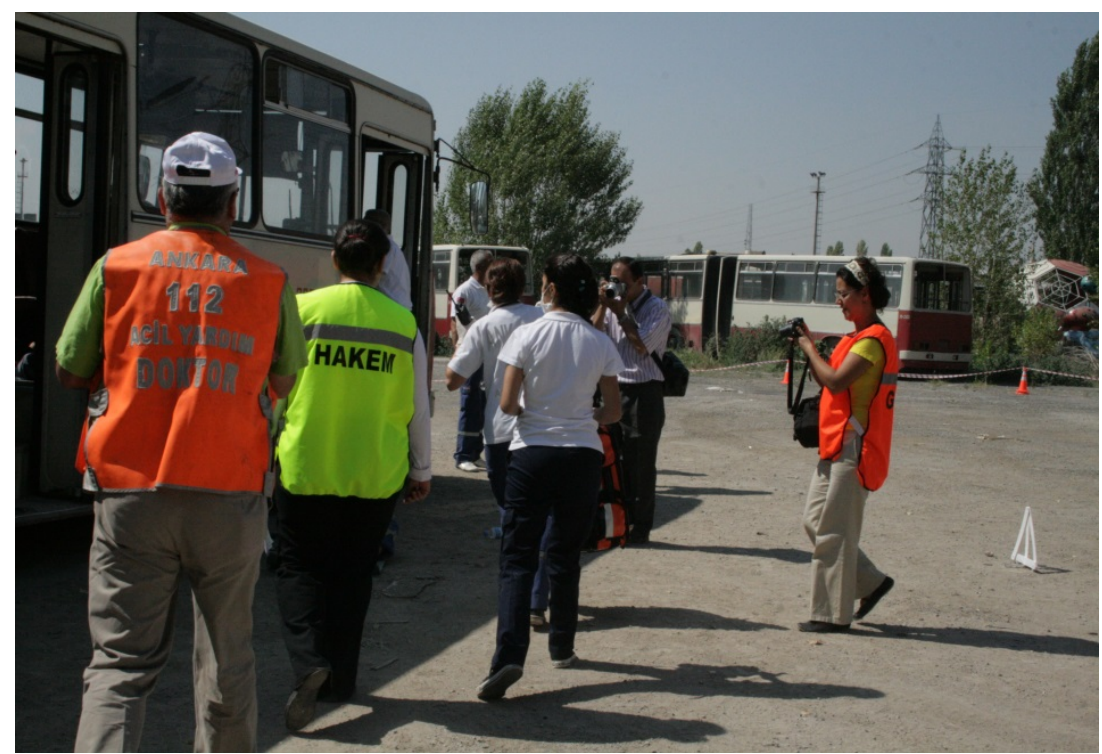

Şekil 4: Ankara UMKE- Ankara 112 Ortak Çoklu Yaralanma Tatbikatı Denetimcileri (hakem)

- Bu senaryoyu denetleyiciler bellidir. Denetleyicilerde, tatbikat icrası yapacak ekipler de denetleyicilerin kimler olduğunu bilmektedir.

- Denetim kriterleri bellidir. Denetim kriterleri denetimci ekibe bir eğitimle (veya toplantı ile) anlatılır. Neler yapması, nasıl yapması ve denetlenmesi ve/veya ölçülmesi istenen şeyler tek tek anlatılır. Formlar önceden denetimcilere verilir.

- Hazırlanan denetim formu katılımcılar tarafından bilinir. Denetim formlarını tatbikat icrası yapacak olan ekipler de görebilir, görmelerinde herhangi bir sakınca bulunmamaktadır.

- Hedefler ve ölçülecek olan kriterler bellidir. Bunu denetimciler ile tatbikat icrası yapacak ekiplerin bilmesinde sorun bulunmamaktadır. Amaca bunu bilmelerinde sakınca yoktur. Ancak yönetim bunu göstermek istemeyebilir. Her iki durumda da amaçla çelişen bir şey yoktur.

- Tatbikat sonucunda değerlendirme toplantısı yapılarak tatbikat sonuç raporu hazırlanır.

- Tatbikatta her aşamayı değerlendirmek için fotoğraf ve video çekimleri yapılır.

\subsection{Yarı Haberli Tatbikat}

- Bu tatbikat türünde senaryo bellidir. Haberli tatbikattaki gibi eğitimler ve toplantılar, provalar yapılabilir. Hazırlıklar da aynen haberli tatbikatta olduğu yapılmalıdır.

- Kimlerin katılacağı herkesçe bilinir, tatbikat icrası yapacak olanlar ile denetimciler ve yöneticiler dahil olmak üzere.

- Katılımcılara senaryoya göre ne yapmaları istendiği anlatıır.

- Bu senaryoyu denetleyiciler bellidir.

- Denetim kriterleri bellidir. Eğer senaryoya yeni enjeksiyonlar yapılabilir, bunu denetimciler bilir. Tatbikat icracıları bunu bilmez. Bu yeni durumun denetim kriterleri önceden denetimcilere verilir. Bu enjeksiyon eklenebilir veya eklenmeyebilir, bu yönetimin vereceği bir karardır.

- Nerede ve ne zaman yapılacağını katılımcılar bilmez.

- Her türlü hazırlık yapılır ama bilinmezler vardır. Senaryoya ilave enjeksiyonlar yapılabilir. Böylece tatbikat icracıları ortaya çıkabilecek yeni durumlara karşı tepkileri alacakları pozisyonlar ve işlemlerin neler olduğu test edilmek istenebilir. Yeni enjeksiyona göre süre uzayabilir. Lojistik destek ekibinin buna göre hazırlıklı olması istenir. 
- Tatbikat sonucunda değerlendirme toplantısı yapılarak tatbikat sonuç raporu hazırlanır.

- Tatbikatta her aşamayı değerlendirmek için fotoğraf ve video çekimleri yapılır.

\subsection{Habersiz Tatbikat}

- Bu tatbikat türünde senaryo bellidir katılımcılar bilmez. Senaryo planlamacılar tarafından hazırlanır, yöneticiler senaryoyu bilir ve onaylar.

- Kimlerin katılacağı bilinir, katılımcılar bilmez. Bu tatbikat türünde planlamacılar tatbikatın bütün aşamalarını planlar. Bütün ekipleri, denetimcileri belirler.

- Katılımcılara senaryoya göre ne yapmaları istendiği anlatılmaz, yöneticileri bilmez. Komuta yönetimi dahil kimseye bilgi vermezler. Kurum amiri, taktik ve stratejik yönetim yapanlar senaryo ve içeriğinden haberdar olur. Operasyonel yönetici senaryo içeriği ve katılımcı ile denetçilerini bilmez.

- Bu senaryonun denetleyicileri bellidir, ama denetimciler bilmez. Denetimciler kimleri denetleyeceğini bilmez.

- Denetim kriterleri bellidir, katılımcılar ve denetimciler bilmez. Amaç rutin işleyiş ile ekiplerin çok iyi bildiği kabul edilen işlerin (mesela ODD'lardaki tepki süreleri, tepki şekilleri) denetlenmesi, işleyişi ölçülmeye çalışılır.

- Nerede ve ne zaman yapılacağı bellidir, katılımcılar bilmez. Amaca uygun biçimde tatbikat yapılacağı için çalışanların neyin, ne zaman hangi kriterlerle ölçüleceğini bilmezler.

- Her türlü hazırlık yapılır ama bilinmezler vardır. Denetim kriterleri planlamacılar il stratejik ve taktik yöneticiler tarafından bilinir. Tatbikat yapan kurum veya kuruluşun gerçek durumunu ortaya koymak amacı varsa o zaman kurum üst yöneticilerine de haber verilmez. Sadece tatbikat yapılacağı söylenir, senaryo içeriği, yeri zamanı büyüklüğü hakkında bilgi verilmez.

- Tatbikat sonucunda değerlendirme toplantısı yapılarak tatbikat sonuç raporu hazırlanır.

- Tatbikatta her aşamayı değerlendirmek için fotoğraf ve video çekimleri yapılır.

\section{4. "X GÜN" Tatbikatı}

- Tatbikatı yönetecek olan taktik ve stratejik yöneticiler ile senaryoyu hazırlayan planlama ekibi bilir. Onun dışında hiç kimse tatbikat hakkında bilgiye sahip değildir.

- Herhangi bir gün herhangi biz zaman diliminde o an belirlenen kişiler belirlenen senaryoya göre tatbikata katılır.

- Senaryo haricinde hazırlık yapılmaz.

- Tatbikat sonucunda değerlendirme toplantısı yapılarak tatbikat sonuç raporu hazırlanır.

- Tatbikatta her aşamayı değerlendirmek için fotoğraf ve video çekimleri yapılır.

\section{Senaryo}

Tatbikat planlaması yapılırken senaryo belirlenmelidir. Senaryoya göre personel sayısına, tatbikatta kullanılacak malzemelerin belirlenmesine, tatbikat yapılacak yerin/mekanın belirlenmesi açısından önemlidir. İki senaryonun amacı farklıdır. Serbest oynamaya yönelik senaryolar, yöneticilerin görevleri yerine getirirken en üst düzeyde izin verilir. Aksine, kontrollü oynamaya yönelik senaryolar, yöneticilerin önceden belirlenmiş olaylara tepki olarak özel eylemler gerçekleştirmelerine neden olur. Kontrollü oyun senaryoları, spesifik afet/ODD personeli, hayatta kalabilme yeteneği veya belirli koşullar altında kombine malzeme ve hizmet görevleri üzerinde egzersiz yapmak için egzersiz amaçları yapmak için en iyi şekilde kullanılır. Olaylar, taktik faaliyetlerin özlü yazılı ifadeleridir. Plancılar, onları kronolojik sırayla listeler ve ne zaman gerçekleşeceğini tahmin eder. Olaylar, olaylar ve ek bilgiler olayların bir 
çizelgesi ve senaryonun bir muhafazası haline gelir. Kasa, kronolojik olarak sütun formatında düzenlenmiş kısaltılmış bir yayındır. Belirli bir durum için planlanan etkinlik, zaman, mekân, katılan tatbikat oyuncuları veya birimler için hazır bir endeks sağlar. Plancılar, tatbikat provası yapıldıktan sonra bu zaman tahmini ayarlamalıdır. Serbest oynamak için kullanılan senaryolar için, olayların zaman çizelgesi, kontrollü bir oynatma senaryosundan daha detaylı olacaktır. Olayların zamanlamasındaki öğeler, çeşitli sistemler içindeki veya arasında oyuncular tarafından belirli eylemler veya reaksiyonlara neden olur. Olaylar programı, kontrolör ve hakem personeli tarafından takip ve gözlemlere izin vermek için yeterli bilgi sağlamalıdır (Exercise planing, 2017).

- Öncelikle tatbikat amacı ve hedefler belirlenir.

- Ölçülmesi istenen kriterler belirlenir.

- Denetim kriterleri belirlenir.

- Yapılması istenenler senaryoya konulur, senaryonun başladığı saat yazılır.

- Tatbikatın nerede, ne zaman, kimlerle, ne şekilde olması gerektiği, hangi müdahalelerin yapılması beklendiği, süresi, haritası, zaman çizelgesi belirlenir (Homeland Security, 2004).

\section{Malzeme Planlaması}

Planlama ve masa başı tatbikat malzemeleri alınır. Yapılacak tatbikata yönelik kullanılacak araç, donanım, çadır, kişisel malzemeler, giysiler, özel malzemeler önceden katılımcılara verilmesi sağlanır. Toplantı odaları (tatbikat türüne göre) ile bilgisayar, projeksiyon cihazı, kalem, kâğıt, not defterleri, haritalar vb. malzemeler sağlanır. Ayrıca hakem, yöneticiler ve bağımsız gözlemcilere farklı renklerde yelekler planlanıp alınmalıdır. Tatbikatta kullanılabilecek, aydınlatma araçları, iletişim araçları, güvenlik bantları, güvenlik konileri, uyarı levhaları, ışıklı uyarı levhaları, sinyalizasyon malzemeleri, megafon vb. gibi malzemeler tatbikat öncesinde tamamlanarak araca konulur. Yine tatbikat süresince tatbikat icrasındaki oyuncuların ve seyircilerin su ve gıda dahil her türlü lojistik ihtiyaçları karşılanmalıdır (Homeland Security, 2004, Smith vd., 2006).

\section{Personel Planlaması}

Planlama grubuna katılacak personelin sayısının belirlenmesi lazımdır. Planlama ekibi senaryoya göre tatbikat oyuncularının sayısına karar vermeli, lojistik ekibini de unutmamalıdır. Tatbikata katılacak uygulayıcı personelin sayısı ve kimlerden oluşacağı belirlenmelidir. Yöneticilerin davet edilmesi tatbikat için en elzem işlerden birisidir. Çünkü yöneticilere kendi kurumlarının durumları net biçimde gösterilmelidir. Teknik destek personeli tatbikatta görev alan bütün personele gıda, su, çay ve tatbikatta intiyaç olacak olan malzemeleri temin eder. Tatbikat makyaj ekibinin planlaması, tatbikatta kullanılacak olan canlı mankenlere makyaj moulage eğitimi almış personelin tatbikat günü tatbikattan takriben iki saat önce tatbikat alanında bulunması sağlanmalıdır. Makyaj ekibi sayısı tatbikatın büyüğü ve tatbikatta kullanılacak olan canlı manken miktarına göre belirlenmelidir. Tatbikat yönetim ekibinin planlanması yapılırken stratejik yönetim, taktik yönetim ve operasyonel yönetim yapacak olan Olay Yeri Yönetim ekiplerinin sayısı net olarak belirlenmelidir. Yönetim ekiplerinin yanlarına veri hazırlama personeli de mutlaka dahil edilmelidir. Yöneticilere yardımcılar planlamada düşünülmelidir. Planlamada yöneticilerin giyecekleri yönetici yelekleri de unutulmamalıdır. Hakem (denetimci) personel planlamasında her bir time bir hakem (denetçi) olacak şekilde yapılmalıdır. Bu kişilerin üzerlerinde denetçi/hakem olduklarını gösteren bir yelek bulunması iyi olacaktır. Bağımsız gözlemci planlaması, tatbikatın objektif gözlerle değerlendirilmesi için gereklidir. Bağımsız gözlemcilere senaryo metni, tatbikat zaman çizelgesi not tutması için gerekirse personel, kalem ve kâğıt sağlanmalıdır. Fotoğraf ve video çekimi yapacak personel yeterli sayıda olmalıdır. Eğer tatbikat birkaç yerde birden 
icra edilecekse buna göre sayı belirlenmelidir. Hem video çekimi hem de fotoğraf çekimi yapılmalıdır. Güvenlik personeli planlamasında, ya kurum veya kuruluşun personelinden bu görevlendirme yapılır ya da resmi güvenlik görevlilerinden güvenlik önlemi alınması sağlanmalıdır. Personel yedeklenmesi mutlaka yapılmalıdır. Tatbikat gününe kadar veya tatbikat günü personelin hastalanması, kaza geçirmesi gibi bazı nedenlerle ekipten birileri tatbikata gelemeyebilir. İlave personel yedeklemesi ile bu sorunlar aşılmalıdır. Her tür personelin yedeklenmesi (yöneticiler dahil) yapılmalıdır. Seyircilerin tatbikata gelmesi sağlanmalıdır. Kurum veya kuruluşların tatbikat icrasında bulunan personeli dışındakilerin tatbikat gösterimine gelmesi, tatbikatı kendi gözlemleri ile değerlendirmeleri uygun olacaktır. Böylece hem kendi eksiklilerini hem de yeni uygulamayı canlı olarak görüp değerlendirme şansına sahip olacaklardır (Homeland Security, 2004, Exercise planning, 2017). Tatbikat için danışma grubu da gözlemci olarak bulunabilir. Tatbikat denetleyicileri ayrıca harici bilgi ve iletişimden sorumlu olarak görevlendirilebilir. Tatbikat denetçisi, tatbikatı askıya almaya bile karar verebilir. Tatbikat denetleyicisi ve oyun denetleyicisi, tatbikatı devam ettirmeli ve tatbikatta değişiklik yapılması gerekip gerekmediğine karar vermelidir (Wilhelmson ve Svensson, 2014).

\section{Toplantılar Ve Görev Dağılımı}

Tatbikatın türünü, kapsamını, amaçlarını ve amacını belirlemek için bir Konsept ve Amaçlar toplantısı düzenlenir ve planlama sürecinin resmi başlangıç aşamasındadır. Toplantısı için olası konular veya konular şunları içerir: Tatbikat amacı, önerilen senaryo, hedefler ve hedefler, tatbikat yeri, tarihi ve süresi, varsayımlar ve yapaylıklar (senaryo akla yatkındır ve sunuldukları gibi olaylar ortaya çıkmaktadır; gizli ajanlar veya hileler soruları yoktur), kontrol ve değerlendirme, güvenlik organizasyonu ve yapısı, lojistiktir (Homeland Security, 2004).

Tatbikat planlama ekipleri aşağıdakileri de içeren ortak ilkelerden oluşan bir kombinasyon kullanır:

\section{Olay Komuta Sistemi (OKS) Yapısı}

Tatbikat planlama ekipleri, OYY tabanlı bir yapıya uyduğunda en etkili ve etkilidir. Bu yapının, Tatbikat Yöneticisi ile biten farklı bir komuta ve hesap birliği zinciri sistemi de dahil olmak üzere pek çok faydası vardır.

\section{Proje Yönetimi}

Etkili proje yönetimi, kritik ve destekleyici görevlerin tanımlanmasını, geliştirilmesini ve yönetilmesini sağlar; Proje statüsü hakkında sıklıkla iletişim; yönetim planlarını ve zaman çizelgelerini (örn., Görev çizelgeleri, Gantt çizelgeleri) kullanılmasını sağlar.

\section{Açıkça Tanımlanmış Roller ve Cevaplar}

Tatbikat planlama ekibi üyeleri, bireysel sorumluluklarının ve takım sorumluluklarının farkında olmalıdır. Görevler tanımlanmalı ve uygun bir planlama ekibi üyesinin görevine verilmeli ve kesin son tarihler oluşturulmalıdır.

\section{Fonksiyonel Alan Becerileri}

Gerçekçi ve zorlu bir senaryonun seçilmesini ve yargı alanının böyle bir soruna cevap verecek uygun yetenekleri bulunduğundan emin olmak için planlama sürecinde konu uzmanları kullanılmalıdır. Örneğin, biyolojik terörizm senaryosunda, kamu sağlık birimleri ve hastaneler, özel silahlar, taktik ekipleri veya bomba ekibinden daha büyük rollere sahip olacaklardır.

\section{Liderlik}

Ekip üyeleri, danışmanlık, motivasyon, disiplin, personel yönetimi ve zaman yönetimi de dahil olmak üzere uygun liderlik ilkelerini göstermelidir. Takım liderleri ve görevlileri gerektiğinde görevleri devretmelidirler. 
Planlayıcılar, uygulayıcılar, hakemler, komuta ekibi, teknik destek ekibine yönelik bilgilendirme toplantısı yapılır. Burada tatbikatın türüne göre senaryo ve yapılması istenenler anlatıır. Ayrıntılar atlanmadan gerekirse adım adım masa başında görev tanımları açıklanmalıdır. Bu toplantılarda görev dağılımı yapıır. Tatbikatta görev alan herkesin, varsa soruları cevaplanır. Bir tatbikatın küçük veya büyük planlama ekibini garanti edip etmeyeceğine bakılmaksızın, belirli sorumluluklara sahip bazı çekirdek gruplar oluşturulmalıdır. Aşağıda açıklanan çekirdek gruplar, planlama ekibinin potansiyel genişlemesi için temel sağlar (tatbikat kapsamıyla orantılıdır):

\section{Komuta Grubu}

Tatbikat müdürlüğü grubu olarak da bilinen bu grup, tüm tatbikat planlama faaliyetlerinin koordinasyonundan sorumludur. Komut grubu, tatbikat yönetmeni / ön planda görev ve sorumluluklar atayan Öncü Planlayıcı, rehberlik sağlar, Zaman çizelgelerini ve denetim sürecini izler. Emniyet Görevlisi ve İrtibat Koordinatörü, doğrudan Tatbikat Direktörüne rapor verir.

\section{Operasyon Grubu}

Bu grup, katılan ajanslar ya da yargı alanları için teknik ya da işlevsel uzmanların çoğunu sağlar.

\section{Planlama Grubu}

Planlama grubu, politika, plan ve prosedürlerin toplanması ve gözden geçirilmesini içeren değerlendirme / iyileştirme sürecinden sorumludur. Ayrı bir simülasyon bölümü, tatbikata katılamayan ajanslar tarafından simüle edilmiş yanıtlar sunar. Bu grup ayrıca, bu metodolojiyi kullanan alıştırmalar için simülasyon hücresi enjekte eder.

\section{Lojistik Grubu}

Lojistik grubu, tatbikatın dışarıdaki müdahale veya kesinti olmaksızın sorunsuz bir şekilde yerine getirilmesini sağlayan malzeme, malzeme, tesis ve hizmetleri destekler. Bu grup iki bölümden oluşur: hizmet ve destek. Servis bölümü nakliye, barikat, tabela, yiyecek ve içecekler, gerçek hayatta tıbbi kabiliyet ve tatbikat alanı çevre güvenliği sağlar. Destek bölümü, mağdur aktörlerin iletişim, satın alma, genel malzemeler, Çok Önemli Kişiler (VIP) / gözlemci işlemleri ve işe alım / yönetim imkânı sağlar.

\section{Yönetim / Finans Grubu}

Yönetim / finans grubu, tatbikat geliştirme boyunca hibe yönetimi ve idari destek sağlıyor. Bu grup aynı zamanda kayıt sürecinden sorumludur ve Tatbikat Direktörü için koordinatları düzenlemektedir (Homeland Security, 2004; Exercise planing, 2017; Working in a Military Headquarters, 2017).

\section{Zaman Çizelgesi Hazırlanması}

Senaryonun başladığı saat senaryoda belirtilir. Senaryonun başladığı andan itibaren olayın ve yapılanların niteliğine göre zaman dakika dakika veya saat saat bir çizelge ile gösterim sağlanır. Uygulayıcılar, yöneticiler, denetimciler ve bu tatbikatta kim ne şekilde görev alıyorsa çizelgede görevleriyle yaptıkları gösterilmelidir. Zaman çizelgesi atölye çalışmaları masabaşı tatbikatlarında kısa süreli, oysa tam zamanlı tatbikatlar çok daha uzun süreli olmaktadır. Zaman çizelgesi, beklenen etkinliklerin ve yazılmış etkinliklerin kronolojik bir olaylar ana sırasına akmasını göstermektedir (Health Services of Los Angeles County, Emergency Medical Services Agency, Disaster Programs, 2017). 


\section{2. İletişim}

Tatbikatta haberleşme nasıl yapılacak önceden planlanmalıdır. Telli, telsiz, cep telefonu, uydu telefonu veya hepsi kullanılacaksa belirlenmelidir. Televizyon, faks ve internet gibi araçlar kullanılabilir. Tatbikatta görev alacak bütün ekiplere telsiz dağıtılmalıdır. Telsizlerin çalışır ve şarjlarının dolu olmasına dikkat edilmelidir. Telsizlerin şarj aletleri de uygulayıcılara verilmelidir. Her ekibin mutlaka bir adı ve bir telsiz kodu bulunmalıdır. Gerekiyorsa ayrı bir seyyar röle kurulmalıdır. Seyyar rölenin enerjisi jeneratörle sağlanabilmelidir. İletişim Mobil Komuta Kontrol Aracı üzerinden sağlanabilir. Seyyar Komutaya Komuta Kontrol Merkezi Personeli konulmalıdır. Tatbikat ortamında bir egzersiz için iki tür iletişim vardır: İç iletişim ve dış iletişim. İç iletişim, egzersiz ağında dahili olarak gerçekleşen tüm iletişimdir. Bu simüle edilmiş çevre / altyapı ile farklı ekipler arasında veya egzersiz ağındaki bilgi paylaşım hizmetleri (örneğin, e-posta, anında mesajlaşma, Voice over Internet Protocol VolP gibi) arasında şifrelenmiş tüneller olabilir. Harici iletişim, düzenli e-posta, telefon, sohbet vb. gibi egzersiz ağının dışında gerçekleşen iletişimdir. Her bir egzersiz için nelerin seçileceğine uygunluk, tercihen, planlama aşamasında veya en geç Pratik hazırlıklar sırasında. Dahili iletişim genellikle dış etkenlere karşı korunmuştur, ancak bu egzersiz ağına ne kadar kolay erişilebildiğine bağlıdır. Harici iletişim egzersiz ağının kullanılabilirliğine bağlı olmayan erişilebilirliği artırabilir, ancak bu, devam eden etkinliklere daha fazla maruz kalma yaratabilir (Wilhelmson ve Svensson, 2014).

\section{Tatbikat Yönetimi}

\subsection{Stratejik Yönetim}

Stratejik yönetimi, Kurum, kuruluş ve işletmenin uzun vadedeki hedeflerine ulaşmasını sağlamak için stratejik planların yapılması, uygulanması ve değerlendirilmesi olarak tanımlanabilir. Stratejik yönetim süreci genel yönetim sürecinden çok farklı değildir. Stratejik yönetim işletmeyi dış çevre unsurlarıyla birlikte yoğun olarak inceler ve uzun vadedeki konumunu belirlemeye çalışır. Genel yönetimin dışında stratejik yönetime ihtiyaç duyulmasının sebebi, iş çevrelerinin hızla değişmesi ve giderek karmaşıklaşmasıdır. Böylece işletmelerin gelecekte de var olabilmesi için sadece bugünü değil geleceği de düşünmesi gerekmektedir. Bu gerçeği kabullenmiş şirketler stratejik yönetime çok önem vermektedirler (Certo, Peter, 1991). Bir organizasyonun ne yaptığını, varlık nedenini ve gelecekte ulaşmak istediği hedefleri ortaya koyan bir yönetim tekniğidir. Stratejik yönetim, gelecekte varmak istediği hedefleri ve bu hedefe nasıl ulaşılacağını gösteren süreci analiz eder. Stratejik yönetim, bir organizasyonun amaçlarına ulaşabilmesi için etkili stratejiler geliştirmesine bunların planlanmasını uygulanmasını ve kontrolünü ifade eder. Yönetimin görevi, insanları, ortak amacı başarabilir duruma getirmek için onların güçlü yanlarını etkili kılmaktır. Kuruluşların başarılarının sürekliliği, hızlı değişmeler karşısında stratejik yaklaşımlarla sorunlara çözüm sunabilmekten geçmektedir. Diğer yandan, kalite ve mükemmellik arayışının arttığı bir dünyada, vatandaşına hizmet üretimi-verimliliği-etkinliği artışı sağlama görevi bulunan kamu kesiminin stratejik yönetim kural ve ilkelerinin uyarlanmasında dikkat edilmesi gerekli özel boyutlar bulunmaktadır. Stratejik yönetim, 5N 1K sorularına alınan cevaplar doğrultusunda amaçlara uygun hedeflere odaklanılmasını sağlama yönü de bulunmaktadır. Bu doğrultuda örgüt kaynakları etkin ve amaca uygun olarak dağıtılarak kullanılabilir. Kuruluşun faaliyetini gerçekleştirdiği iç ve dış ortamın kapsamlı bir biçimde incelenmesini ve değerlendirilmesini içeren ve kuruluşun çevresi ile etkileşim içinde sistematik olarak incelendiği ve yöntemsel olarak kuruluşun güçlü ve zayıf yönleri ile dışsal etkenlerden kaynaklanan fırsatlar ve tehditler belirlendiği GZFT (Güçlü Yönler, Zayıf Yönler, Fırsatlar ve Tehditler) ya da durum analizi olarak adlandırılan analizin yapılarak cevaplandırılacağı "Neredeyiz?". Kuruluşun varoluş nedeninin ifade edilmesi ulaşııması arzu edilen geleceğin kavramsal, gerçekçi ve öz bir ifadesi olan vizyon; kuruluşun faaliyetlerine yön veren ilkeler, ulaşılması için çaba ve eylemlerin yönlendirileceği genel kavramsal 
sonuçlar olarak tanımlanabilecek stratejik amaçlar ve amaçların elde edilebilmesi için ulaşılması gereken ölçülebilir sonuçlar anlamına gelen hedefler ortaya konulduğu "Nereye gitmek istiyoruz?" Yönetsel bilgilerin derlenmesi ve plan uygulamasının raporlanması anlamındaki izleme ve alınan sonuçların daha önce ortaya konulan misyon, vizyon, ilkeler, amaçlar ve hedeflerle ne ölçüde uyumlu olduğunun, kısaca performansın değerlendirilmesi ve buradan elde edilecek sonuçlarla planın gözden geçirilmesini ifade eden değerlendirilmesi süreci "Başarımızı nasıl takîp eder ve değerlendiririz?" sorularına verilen cevaplar kurumun stratejik planlama sürecini ortaya koyacaktır (Aktan ve Tüğen, 2006).

Stratejik yönetimin üç temel özelliği; 1. Önderlik: Stratejik kararlar bir dönemde verilir ve uzun bir dönemde yeni bir stratejik karara kadar değişmezler. 2. Evrensellik: Stratejik kararlar kuruluşun bütün kaynaklarının ve bütün enerjisinin verilen karar doğrultusunda harekete geçirilmesini gerektirir. 3. Belirleyicilik: Stratejik kararlar kendilerinden sonra verilecek bütün kararların ve davranışların tipini ve doğrultusunu belirlerler (Hastürk, 2017).

\subsection{Taktik Yönetim}

Taktik, işletmenin kaynaklarını en etkili bir şekilde kullanabilmek için, "değişen duruma uygun olarak alınan kısa dönemli kararlardır (Dinçer, 1998). Taktik, usul ve teknik bakımdan stratejiden daha ayrıntılıdır. Stratejinin amaçlara ulaşmak için eldeki güçlerin veya kaynakların dağıtım planı olduğunu biliyoruz. Taktik, bu yerleştirilen güçlerin harekete geçirilmesi yani uygulanması ile ilgilidir. Olaylar yaşanırken veya cereyan ederken meydana gelecek durumları önceden görerek uygulama alternatifleri ve ayrıntıları hazırlanır. Taktik, usul ve teknik bakımdan stratejiden daha ayrıntılıdır. Stratejinin amaçlara ulaşmak için eldeki güçlerin veya kaynakların dağıtım planı olduğu bilinmektedir. Taktik, bu yerleştirilen güçlerin harekete geçirilmesi yani uygulanması ile ilgilidir. Olaylar yaşanırken veya cereyan ederken meydana gelecek durumları önceden görerek uygulama alternatifleri ve ayrıntıları hazırlanır. Taktik, stratejilerin uygulanması süresinde karşılaşılan rekabete ve değişen şartlara uygun olarak yapılan dinamik, genellikle nihai sonuca odaklı olmayan ve daha kısa dönemleri kapsayan, olası rakip davranışlarını dikkate alan faaliyetler ve kararlardır. Bu tanımlardan yola çıkılarak taktik daha özel ve daha kısa fikirlerden ve uygulama, sanatından oluşur. Strateji bir nizam, düzen ve tasarı ile ilgili düşünsel bir işlem, taktik ise harekete geçme ve uygulamanın ayrıntılı bir düzeni ile ilgilidir. Bazı hallerde taktik, uygulamalar esnasında saptanabilir (Eren, 2000). Taktik, koruyucu tedbirlerin uygulanması için güvenli ve etkili prosedürlerin geliştirilmesi ile ilgilidir. Bu, çoğu acil durum yönetimi ve acil müdahale grubunun aşina olduğu planlamadır. Taktik planlama sırasında odak noktası hem ana bölge personeli hem de bireysel kampüs yanıt grupları için standart işletim prosedürleri de dahil olmak üzere gerçek tepki eylem planlarını geliştirmeye yöneliktir. Taktik planlama genellikle şunları içerir: İnsanları, mülkleri ve çevredeki çevreyi bu sırayla koruma, Olay tepkisinde doğrudan rol oynayacak personel, ekipman ve kaynakları yönetmek, Eylem planlarının ilçe stratejik ilkeleri ve operasyonel hedefleri ile uyumlu tutulmasıdır (Tasmanian government department of premier and cabinet, 2017).

Taktik yönetimi otomatikleştirmek ve nerede olurlarsa olsunlar, insanlar tarafından yapma gün-gün ve dakika-dakika kararı geliştirmek için çeşitli elektronik, sistemleri ve istatistik araçları uygulamasıdır. Maliyet ve iş hacmi kontrolü yapılır. Göstergelerin ve özel rapor paketlerini oluşturulur. Taktik, planlanmış veya planlanmamış herhangi bir durumda en iyi sonucu alabilmek için tecrübe, fizik üstünlük ve teknik özellikler koordinasyonunu rakibe karşı saldırı olarak kullanabilme sanatına denir. Taktik kullanabilmek veya verilen bir taktiği mükemmel yapabilmek var olan becerilerin eğitimle geliştirilmesine bağlıdır. Taktik, bu yerleştirilen güçlerin harekete geçirilmesi yani uygulanması ile ilgilidir. Taktik daha özel ve daha kısa fikirlerden ve uygulama sanatından oluşur. En iyi hedefi gerçekleştirmek için stratejiye uygun vizyon ve misyonları olan işi/ olayın/kurumun yönetilmesidir. Bunun için 
büyük resme bakmasını bilen zihin ve muhakeme yeteneğine sahip ölçülebilir değerler ve sonuçların değerlendirilerek yorumlama yaparak kısa mesafeli planlamadır.

\subsection{Operasyonel Yönetim}

Operasyonel planlama, bir olay yanıtı sırasında ilçe personelinin ve kaynakların yönlendirilmesi ve kontrol edilmesi ile yerel müdahale eden kişilerle olan ilişkiler ile ilgilidir. $\mathrm{Bu}$ tür planlama, hedeflerin ve hedeflerin geliştirilmesiyle bölgenin stratejilerine kapsam belirlenmesini içerir. Operasyonel planlamanın diğer kritik sonuçları arasında, sorumlu bölge görevlilerine acil müdahale görev ve sorumluluklarının atanması ve ilk yanıt sırasında kullanılacak belirli ilçe kaynaklarının atanması yer alır. Operasyonel plan, organizasyonun stratejik planda belirtilen hedefleri, hedefleri ve stratejileri nasıl yerine getireceğini ayrıntılarıyla anlatmaktadır. Bu eylemlerin yerine getirilmesinden sorumlu olan stratejik plan hedefleri doğrultusunda üstlenilmesi gereken eylemleri ve bu eylemlerle ilişkili zaman çerçeveleri, maliyetler ve kilit performans göstergelerini içerir. Operasyonel plan, stratejik planın ömrü için geçerli olmalı, ancak hedeflere ulaşılmasına yönelik yeterli ilerleme kaydedildiğinden emin olmak için düzenli olarak gözden geçirilmeli ve gerektiğinde öncelikler revize edilebilir. Her bir stratejiye ulaşmak için üstlenilmesi gereken kilit eylemlerin ayrıntılı açıklaması. Her belirli eylemin önemi: düşük, orta ve yüksek. Bu, hangi eylemin planın başında veya sonrasında yapılması gerektiğinin bir göstergesidir. Operasyon Yönetimi, işlerin doğru ve düzenli olarak yapılmasını sağlamayı ve süreci organize etmeyi amaçlar (Tasmanian government department of premier and cabinet, 2017).

Yürütülmekte olan operasyonun yönetimi ifade eder. Tatbikatta ve/veya uygulamada var olan olayla, o anda ortaya çıkan durumları bizzat olayın içinde olup, olayın yürütülmesini içerir. Operasyonel yönetim, yürütülmekte olan operasyon süresiyle sınırlıdır. Operasyon süreci içinde olan bütün unsurlar operasyonel sürece dahildir. Bu sürecin yönetimi bizzat operasyon yerinde olmaktadır. Olay Yeri Yöneticisi olay anında tespit edilir. Operasyonel düzey, nihai ürünlerin müşterilere zamanında teslim edilmesini sağlamak için işlemleri planlar. Stratejik ve taktik düzeylerin aksine, çok aşamalı, çok uluslu operasyonları planlamak için çok az araştırma yapılmıştır. Bunun bir nedeni, zamanlama problemlerinin, yönetimin merkezileştirme derecesine, yöneticileri değerlendirmek için kullanılan performans ölçümlerine ve süreç konfigürasyonuna odaklanmasıdır. Bununla birlikte, operasyonel düzey müşteri hizmetini önemli ölçüde etkileyebilir, bu nedenle birleşik bir lojistik sistemi sağlamada önemli bir bileşen oluşturur. Operasyonel seviyedeki odağı müşteri varış yerinde sipariş tesliminden sipariş teslimine kadar olan süreyi en aza indirgemek için nereye ve ne zaman monte edileceğine yöneliktir (Schmidt vd, 2017).

Operasyon yönetimi, örgütlerin mal ve hizmet üretme biçimiyle ilgilidir. Kütüphaneden ödünç aldığınız her kitap, hastanede aldığınız her tedavi, bir mağazada beklediğiniz her hizmet, bir şeyler giydiğiniz, yediğiniz, oturur, kullandığı veya okuduğu her şey birisi tarafından üretilmiştir. İşlem Yönetimi'nin temel nitelikleri söz konusudur Bir iş, bir takım kaynakları (Girdi) hizmetlere ve mallara (Çıktı) dönüştüren dönüştürücü bir süreçtir. Giriş kaynakları, hammadde, bilgi veya hatta müşterinin kendisi olabilir. Operasyon Yönetimi birçok farklı disiplin içerir. Etkili olabilmek için, Operasyonlar, bir organizasyon içinde çok sayıda farklı disiplinle etkileşime girer (Carlson school of management employer education services, 2009).

\section{Tatbikat Komutası}

Tatbikat komutası planlama içinde gösterilmelidir. Tatbikat komutasını kim yürütecek önceden belirlenmelidir. Tatbikat yönetimi nasıl yapılacak önceden belirlenmelidir. Tatbikat Komutası için gerekli olan ekipmanlar belirlenmelidir. Mobil Komuta Kontrol aracı, telsiz, güvenlik konileri, triaj brandaları, megafon, seyyar röle, jenaratör vb malzemeler önceden 
hazırlanmalıdır. Tatbikat yönetim yeri belirlenmelidir. Burası mümkün olan en iyi görüş açısına sahip olmalıdır. Olay Yeri Yönetimi, Komuta Yönetimi ve Olay Komuta Yönetimi ayrı ayrı olacak şekilde ve koordineli olarak yapılmalıdır. Tatbikat Komutası iki ayrı aşamadır. Birincisi Olay Yeri Yönetimi(OYY), ikincisi ise Komuta Yönetimidir (KY). Ayrıca bu iki yöneticiyi (OYY yöneticisi ve $K Y$ yöneticisi) üzerinde bir koordinatör görev alır. İkisi arasındaki koordinasyonu ve dış koordinasyonu sağlar. Yalnız bu yapılanma dikey hiyerarşik değildir. Komutadaki yöneticiler duruma göre üst düzey yönetici olurlar. Komuta Kontrol Yöneticisi bazen üst amir, bazen de koordinatör üst amir olabilir. Bir tatbikat yöneticisi, bir yardımcısı, iki veri giriş elemanı, afet veya ODD'larda ayrı bir danışman hekim görevlendirilebilir. Bu aynı zamanda işi bilen (tecrübeli) ekip dışında farklı üç komuta personelinin eğitimi de sağlanmalıdır. Teknik destek ekibi OYY yöneticisi emrinde olmalıdır. İhtiyaç olması halinde ekibe her türlü teknik destek (malzeme, ilaç, ambulans, basit bakım onarım vb) sağlanmalıdır.

\section{Prova}

Tatbikat yapılacak alan önceden belirlenmeli, senaryoya görevlerin icra yerleri tespit edilir, görev alacaklara nerelere gönderilecekler nasıl nerede ne gibi işlemler yapılacak, önceden kroki üzerinde işaretlenir. Tatbikatı yapmadan önce provalarının yapılması gerekmektedir. Provalarda tatbikatlarda görevlendirilen kişilere yapacakları uygulamalı olarak gösterilir. Tatbikatın "gerçekmiş" gibi yapılabilmesi için görev alacakların tam bir ciddiyet içinde görevlerini yerine getirmeleri gerekmektedir. Gerekiyorsa makyaj ve moulage uygulamaları yapılmalıdır. Makyaj moulage kitleri varsa yapılması işin gerçekçi yapılması açısından önemlidir. Bu durumda tatbikat icrasına katılacak olanlar işi daha ciddiye alarak provaları yapmaktadırlar. Provada yanlış yapılıyorsa, gerekirse prova durdurulmalı yapılan yanlış anında düzeltilmelidir (haberli ve yarı haberli tatbikatta). Provalarda ve tatbikatta hiçbir zaman güvenlikten ödün verilmemelidir. Güvenlik açığı olmamalıdır (Exercise planing, 2017; Working in a Military Headquarters, 2017).

\section{DIKKAT !!!}

Tatbikatta mutlaka "Emniyet Pimi" uygulaması yapılmalıdır. "Emniyet Pimi” uygulaması tatbikat yapılırken gerçekten rahatsızlanan veya yaralanan kişiler için kullanılan bir kelimelik paroladır. Duruma göre tatbikat tamamen durdurulmalı veya sadece rahatsızlanan kişinin can ve sağlık güvenliği sağlanacak şekilde tatbikattan alıkonulmalıdır. Diğer kurum ve kuruluşlar da provalara çağrılmalıdır. İşbirliğini nasıl yapılacağı, koordinasyonun nasıl sağlanacağı, varsa hataların nasıl düzeltileceği provalarda işlenmelidir.

\section{Tatbikat İcrası}

Seyirciler kendilerine ayrılan yerde tatbikatı izler. Tatbikat alanı tam güvenlik sağlandıktan sonra icraya geçilir. Tatbikat, belirlenen kurallar ve disiplin içinde kesilmeden icra edilir. Yönetim ve koordinasyona dışarıdan müdahale edilmez. Bütün sorumluluk tatbikat yöneticisindedir. Diğer kurumların yardımına ihtiyaç varsa durum değerlendirilmesi yapılarak, onlardan destek alınmalı iş birliği ve koordinasyon provalarda olduğu gibi yapılmalıdır. İşlem bittikten sonra hasar tespiti yapılması gerekiyorsa hasar tespit ekibinin burada görevlendirilerek, işin yapılmasının sağlanması gerekmektedir.

\section{Tıbbi Yardım}

Tatbikatlarda istenmeyen olaylarla plan içinde olmasa da karşılaşılabilir. Bu nedenle güvenlik tatbikatlarda vazgeçilemeyecek unsurlardan olması gerekir. Güvenlik pimi denilen sistem kurulmalıdır. İstenmeyen olaylarla karşılaşıldığında tatbikat anında durdurulur. Tıbbi yardım 
yapılır. Tatbikat provalarında ve tatbikat süresi boyunca tıbbi yardım planlaması bulunmalıdır. Tatbikatın büyüklüğüne ve alanın genişliğine bağlı olarak acil yardım ambulansı ve ekibi bulundurulabilir (Wikipedia, 2017).

\section{Basın}

Bu görevin zorluklarına gerçekçilik kazandırma, medyayı ve halkı tatbikata dahil ederek yaratılabilir. Böyle bir oyunun amacı tatbikat sırasında katılımcılara baskı yapmaktır. Gazetecilere veya diğer kişilere, katılımcıları harekete geçirmek için çeşitli yollarla (örneğin, genel halk, mağdurlar veya akrabaları) farklı roller oynamaları istenebilir. Serbest gazeteciler, tatbikat sırasında medyanın rolünü oynamak için çağrılabilir. Bir seçenek gazetecilik öğrencilerini tatbikatlara dahil etmektir. Genellikle, gazetecilik okulları, bu gibi alıştırmalara katkıda bulunmaktan memnuniyet duyar. Medya temsilciliğini yürütenler, diğer şeylerin yanı sıra, katılımcılar ile basın toplantıları ve röportajlar düzenleyebilirler. Tatbikat sırasında bazı kilit kişilere medya eğitimi vermek için genellikle, arzusu ve arzusu olabilir. Görüşme teknikleri ve bir kamera karşısında konuşma konuyla ilgili uzmanlar ve danışmanlar yardımıyla kolayca organize edilebilir. Bunu daha az insanla daha küçük ölçekte yapmak daha fazla kişisel geri bildirim ve bu nedenle medya eğitimini özümsemek ve içselleştirmek için daha iyi bir fırsat sağlar (Wilhelmson ve Svensson, 2014). Basın açıklaması için resmi kurumlarda en üst düzeyde resmi izinlerin alınması, bunun için basın bilgilendirmesi yapacak kişi veya kişilerin belirlenmesi gerekmektedir. Basının çalışacağı alan belirlenmelidir. Onların rahat çalışması, kurum veya kuruluş için olumlu hava yaratması için imkanlar sağlanmalıdır. Basın açıklamasının nerede ve nasıl yapılacağı, hangi aralıklarla bunun uygulanacağı basın mensuplarına duyurulmalıdır.

\section{Raporlama ve Değerlendirme}

Tatbikat bittikten sonra komuta yönetimi ile uygulayıcılar raporlarını yazmalıdır. Bu tatbikattan sonraki iki saat içinde olmalıdır. Tatbikatın tüm katılımcıları ile tatbikat değerlendirilmesi toplantısı ve bitiş raporu hazırlanmalıdır. Tatbikat değerlendirmesi Katılan tüm birimlerin eksiklik, hata ve başarılarının ortaya koyulduğu bir tatbikatın en önemli aşamasıdır. Ortada gerçek bir acil durum veya afet yokken, yapılabilecek yanlışların ve koordinasyon sıkıntılarının objektif tespiti ve irdelenmesi tatbikatın başarısı için gereklidir. Tatbikat denetçilerinin gözlem ve tespitlerine dayanılır. Katılımcıların yürüttüğü faaliyetler değerlendirilir. Kurumlarca, tatbikatın raporlanması yapılır. Değerlendirme kriterleri Acil veya afet durumuna uygunluğu, senaryo içeriğindeki tanımlar ve olayların yeterliği, kaynak veya araç kullanım düzeyi ve zamanlaması, mesaj alışverişinin işleyiş düzenindeki başarı oranı, katılımcıların acil sorunlara çözüm bulma düzeyi, çalışma grupları arasındaki uyumun derecesi, senaryodaki sürelerden ne kadar sapma olduğu, hedeflenen amaçlara ulaşılma oranları ayrı ayrı belirlenmiş sonuçlara ne oranda ulaşıldığı bu raporlarda gösterilmelidir. Planların tatbikatla denenmesi, afet ile ODD öncesinde yapılan eğitim ve tatbikatlarla bu planlar geliştirilir ve güncelleştirilir. Yerel ölçekte doğal tehlike ve riskler belirlenerek, acil durum veya afet senaryoları da oluşturulmalıdır. Afet senaryolarına dayanan, müdahale planları hazırlanmalıdır. Plan görevli personelin eğitim ve becerileri geliştirilmelidir. Afet müdahale ve acil yardım planları, yerel imkan ve kaynaklarla sürekli güncel ve el altında tutulmalıdır. Arama ve kurtarma personelinin eğitimi, özel hazırlanmış tatbikat alanında teorik ve uygulamalı olarak yapılmalıdır, Halkın da katılımıyla düzenlenecek genel tatbikatlarla, planların uygulanabilirliği denenmeli, aksaklık ve hatalar düzeltilmelidir. Yerel yöneticiler ve kamu görevlileri, afet acil durum planlarına önem vermeli ve gerektiğinde ilk önce bunları kullanmalıdırlar (NATO, 2017). 


\section{Sonuç}

Sonuç olarak, tatbikat hazırlama ve yönetme belirli amaç, kapsam ve hedefleri olan konu hakkında kurumun tatbikat anındaki durumunu görmek, kurum veya kuruluşların kendilerine değerlendirmelerini sağlamak, değerlendirme raporlarıyla da gelişime yönelik konuların belirlenmesini sağlamak temel değerler olmalıdır. Bu bölüm Ankara UMKE'nin il tatbikatları, bölge tatbikatları ile ulusal tatbikatların planlanması, hazırlıkları ve uygulamaları da göz önüne alınarak içinde ampirik bilgilerin olduğu ancak kanıtlanmış bilgilere dayanan şekilde hazırlanmıştır. Süreç üst yönetimin taahhüdünü, uygun bir organizasyonel bağlamın oluşturulmasını ve uygun kaynakların tahsisini gerektirir. Bir olayın veya acil durumun meydana gelmeden önce, stratejik planlama süreçleri, yaşamı korumak ve / veya mülkiyetini korumak için alınan önlemlerle ilgili kararlar almak için kullanılır ve tanımlanan tehditler ve tehlikelere göre stratejik planlama süreçleri kullanılır. Taktik planlamanın en yüksek kalitesinde mevcut boşlukların belirlenmesine ve boşlukların giderilmesine yönelik hükümler bulunmasına neden olabilir.

\section{Kaynakça}

Aktan, C.C. (ed), Tüğen, K., (2006), "Performans Esaslı Bütçeleme Sistemi”. Kamu Mali Yönetiminde Stratejik Planlama ve Performans Esaslı Bütçeleme, Ankara: Seçkin Kitabevi.

Carlson school of management employer education services, (2009), Introduction to operations management, 17.01.2017, Erişim Adresi: https://www.academia.edu/13169819/ Carlson_School_of_Management_Employer_Education_Services.

Certo SC., Peter JP., (1991), Strategic Management; Concepts and Applications, 2.Edition, Mcgaw-Hill, U.S.

County of los angeles department of health services emergency medical services agency disaster services, Conducting drills and exercises a guide for hospitals, 17.01.2017, Erişim adresi: http://file.lacounty.gov/SDSInter/dhs/206687_Conducting Drills_Exercise30806.pdf

Dinçer, Ö., (1998), Stratejik Yönetim ve İşletme Politikası, Beta Basım Yayım A.Ş. İstanbul

Eren, E., (2000), Stratejik Yönetim ve İşletme Politikası, Beta Basım Yayım A.Ş. İstanbul

Esin, S., Oğuzhan, T., Kaya K.C., Ergüder, T., Özkan, A.T., Yüksel, İ., (2001), Afetlerde Sağlık Hizmetleri Yönetimi. Ankara: 1. Baskı. T.C. Sağlık Bakanlığı Sağlık Projesi Genel Koordinatörlüğü Yayını.

Exercise planing, 16.01.2017, Erişim adresi: http://www.globalsecurity.org/ military/library/policy/ army/fm/25-4/Ch2.htm,

FEMA, Training and Exercise Plan Workshop User's Handbook, 17.01.2017, Erişim adresi: www.training.fema.gov/programs/emischool/el361toolkit/assets/tepw_users_handbook.pdf

Free Team Building Games - Guide And Tips, 16.01.2017, Erişim adresi: http://www.businessballs.com/teambuilding.htm,

Hastürk, M., Stratejik Planlama ve Performans Esaslı Bütçeleme, 17.01.2017, Erişim adresi: www.erkankaraarslan.org/wp-content/uploads/2012/10/4.1-Stratejik-Planlama-ve-

PerformasEsasl\%C4\%B1-B\%C3\%BCt\%C3 \%A7eleme.pdf 
Homeland Security, Exercise and evaluation program, volume III: Exercise program management and exercise planning process, July 2004, Erişim adresi: https://www.hsdl.org/ ?view\&did=449375, 16.01.2017

İş Sağlığı ve Güvenliği Kanunu (2012, 30 Haziran), Resmi Gazete (Sayı: 28339), Erişim adresi: http://www.resmigazete.gov.tr/eskiler/2012/06/20120630-1.htm

İşyerlerinde Acil Durumlar Hakkında Yönetmelik (2013, 18 Haziran), Resmi Gazete (Sayı: 28681) Erişim adresi: http://www.resmigazete.gov.tr/eskiler/2013/06/20130618-8.htm

NATO, 17.01.2017, Bi-Sc Collective Training and Exercise Directive (ct\&ed) 075-003, Erişim Adresi: www.act.nato.int/images/stories/structure/jft/bi-sc-75-3 final.pdf

Örnekleriyle Türkçe Sözlük, Milliği Eğitim Bakanlığı Yayınları no: 2967, Milli Eğitim Basımevi, İstanbul 2000.

Özdemir, P., İlki, A., 2003, Eğitimler ve tatbikatlar, 16.01.2017, Erişim adresi: http://www.gapsel.org/condocs// ekutuphane/010_au_d10- egitimlervetatbikatlar.pdf

Schmidt, G., Wilbert, E., Wilhelm, W.E., 17.01.2017, Strategic, Tactical and Operational Decisions in Multi-national Logistics Networks: A Review and Discussion of Modeling Issues, Erişim Adresi: $\quad$ https://www.researchgate.net/publication/242398509 Strategic_Tactical_and_Operational_Decisions_in_Multi-national_Logistics_Networks_A_ Review_and_Discussion_of_Modeling_Issues

Smith, G.L., Pearson-Taylor, J., Andersen, D.C. (2006), The evolution of strategic long-term planning at anglo platinum. Proceedings of the Second International Platinum Conference, Sun City, South Africa, 8-12 October 2006. Southern African Institute of Mining and Metallurgy, Johannesburg.

Tasmanian government department of premier and cabinet, Sport and recreation tasmania strategic and operational planning toolkit, 17.01.2017, Erişim Adresi: http://www.dpac.tas.gov.au/_data/assets/pdf_file/0003/228522/Strategic_

Operational_and_Planning_Toolkit.pdf

Tatbikat, Açıklamalı Afet Yönetimi Terimleri Sözlüğü, 16.01.2017, Erişim adresi: https://www.afad.gov.tr/upload/Node/3495/xfiles/sozluk.pdf,

Wikipedia, 17.01.2017, Medical Support in Disaster Exercise, Erişim Adresi: https://en.wikipedia.org/wiki/ Union_Shield_\%E2\%80\%93_2011\#Exercise_planning

Wilhelmson ve N., Svensson, T., (2014), Handbook for Planning, Running and Evaluating Information Technology and Cyber Security Exercises, Center for Asymmetric Threat Studies (CATS), Published by: The Swedish National Defence College, Printed by Elanders Sverige $A B$, Vällingby.

Working in a Military Headquarters (Exercises and Operations), Deployee Guide, 16.01.2017, Erişim adresi: http://sclr.stabilisationunit.gov.uk/publications/deployee-guideseries. 